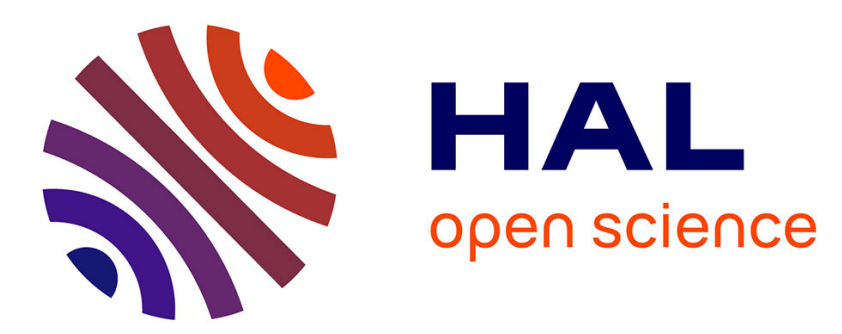

\title{
The native form of thePlasmodium falciparum Pf68 neutral proteinase is a 105,000-Da polypeptide
}

Philippe Lawton, Christine Barrault, Philippe Grellier, Joseph Schrével, Hans-G Heidrich

\section{- To cite this version:}

Philippe Lawton, Christine Barrault, Philippe Grellier, Joseph Schrével, Hans-G Heidrich. The native form of thePlasmodium falciparum Pf68 neutral proteinase is a 105,000-Da polypeptide. Parasitology Research, 1991, 77 (8), pp.720-722. 10.1007/BF00928690 . hal-02110651

\section{HAL Id: hal-02110651 \\ https://univ-lyon1.hal.science/hal-02110651}

Submitted on 26 Apr 2019

HAL is a multi-disciplinary open access archive for the deposit and dissemination of scientific research documents, whether they are published or not. The documents may come from teaching and research institutions in France or abroad, or from public or private research centers.
L'archive ouverte pluridisciplinaire HAL, est destinée au dépôt et à la diffusion de documents scientifiques de niveau recherche, publiés ou non, émanant des établissements d'enseignement et de recherche français ou étrangers, des laboratoires publics ou privés. 


\title{
The native form of the Plasmodium falciparum Pf68 neutral proteinase is a $105,000-D a$ polypeptide
}

\author{
Philippe Lawton $^{1}$, Christine Barrault ${ }^{2}$, Philippe Grellier ${ }^{2}$, Joseph Schrével ${ }^{2,3}$, and Hans-G. Heidrich ${ }^{1}$ \\ ${ }^{1}$ Max-Planck-Institut für Biochemie, W-8033 Martinsried, Federal Republic of Germany \\ ${ }^{2}$ Laboratoire de Biologie Cellulaire, Université de Poitiers, F-86022 Poitiers, France \\ ${ }^{3}$ Museum National d'Histoire Naturelle, F-75231 Paris, France
}

Accepted July 1, 1991

As in many physiological processes in eukaryotic cells, proteases play an important role in plasmodia. Enzymedependent processes in the malaria parasite include hemoglobin digestion during schizogony and invasion of the host erythrocyte by merozoites (reviewed by Schrével et al. 1990). In recent investigations, particular emphasis has been placed on neutral proteases because if they are present in the parasite but not in the host, they can serve as possible targets for the designing of new drugs against malaria.

Fast protein liquid chromatography (FPLC) purification of a neutral Plasmodium falciparum proteinase (Grellier et al. 1989) with an isoelectric point of 4.4, an optimal activity at $\mathrm{pH} 7.5$ and a specificity for the synthetic peptidic substrate GlcA - Val - Leu - Gly - Lys AEC yields an enzymatically active fraction that contains several proteins. Polyacrylamide gel electrophoresis using sodium dodecyl sulfate (SDS-PAGE) revealed a major component exhibiting an apparent molecular weight of $68 \mathrm{kDa}$ and other components displaying apparent molecular weights of 97 and $38 \mathrm{kDa}$. We suspected that the low-molecular-weight components might result from processing during the isolation steps. Such processing can best be recognized by using an antibody against the native, as yet unknown, form of the neutral protease.

Polyacrylamide gel electrophoresis in the absence of SDS (PAGE; Rothe 1988) was performed on trophozoite/schizont extracts from the FCB1 strain of $P$. falciparum from Colombia (extracted after saponin treatment in the presence of $10 \mathrm{~mm}$ Zwittergent 3-12 (Calbiochem); $2 \%$ (v/v) aprotinin (Bayer); 2 mm PMSF (phenylmethane sulfonyl fluoride); and pepstatin, bestatin and antipain (Sigma; final concentration, $1 \mu \mathrm{g} / \mathrm{ml}$ ). The activity against the synthetic peptide substrate correlated with a smeary doublet of 105 and $97 \mathrm{kDa}$. The $105-\mathrm{kDa}$ band was electro-eluted from the gel and used in rabbits to produce an anti-Pf105 antiserum, a key reagent in further experiments.

Offprint requests to: $\mathrm{H} .-\mathrm{G}$. Heidrich
As expected, this antibody $(1: 100$ or $1: 200$ dilution) recognized a $105-\mathrm{kDa}$ protein in extracts from trophozoites, schizonts and free merozoites (isolated according to Heidrich et al. 1983) in immunoblots and immunoprecipitations (using protein A-Sepharose Cl-4B; data not shown). No erythrocyte or serum component was recognized. The antibody also recognized the 97-, 68and $38-\mathrm{kDa}$ polypeptides from the chromatographic isolation (data not shown) but failed to recognize protein(s) exhibiting higher molecular mass(es). The parasitic origin of all of these proteins was demonstrated by metabolic $\left[{ }^{35} \mathrm{~S}\right]$-methionine labeling. Since the antibody recognizes the 105-, 97-, 68- and 38-kDa polypeptides, it is clear that these polypeptides must be related to each other, suggesting that the low-molecular-weight products could derive from a common precursor molecule, the $105-\mathrm{kDa}$ polypeptide. The enzymatic activity of this molecule was inhibited by the anti-Pf105 antibody as determined using the synthetic peptide substrate (Fig. 1). Thus, the $105-\mathrm{kDa}$ polypeptide is likely to be the native neutral proteinase.

The $105-\mathrm{kDa}$ protein is proteolytically processed in vitro. The dependence of the Pf105 processing on the extraction buffers and proteinase blockers used is shown in Fig. 2. A processing product of $97 \mathrm{kDa}$ (first step of processing) appeared during freeze-thawing and/or further handling of the aqueous and buffered trophozoite/ schizont/merozoite extracts in the absence of proteinase inhibitors at $4^{\circ} \mathrm{C}$ for a short period $(<2 \mathrm{~h}$; Fig. 2, lane g). No such proteolysis was observed when protease inhibitors known to inhibit the neutral proteinase activity (Grellier et al. 1989) were included in the media. These inhibitors included $\mathrm{ZnCl}_{2}$, iodoacetamide, leupeptin, antipain and TLCK $(N \alpha-p-$ tosyl-L-lysine $)$ chloromethyl ketone; Fig. 2, lanes a-e). EDTA (ethylenediamine tetraacetate), pepstatin and PMSF did not prevent formation of the 97-kDa product (Fig. 2, lanes h-j). The $68-\mathrm{kDa}$ product (second step of processing) was observed only in water extracts in the absence of protease inhibitors after at least $4 \mathrm{~h}$ at $\geq 4^{\circ} \mathrm{C}$ (Fig. 2, lane f) and could be prevented by all of the protease blockers 


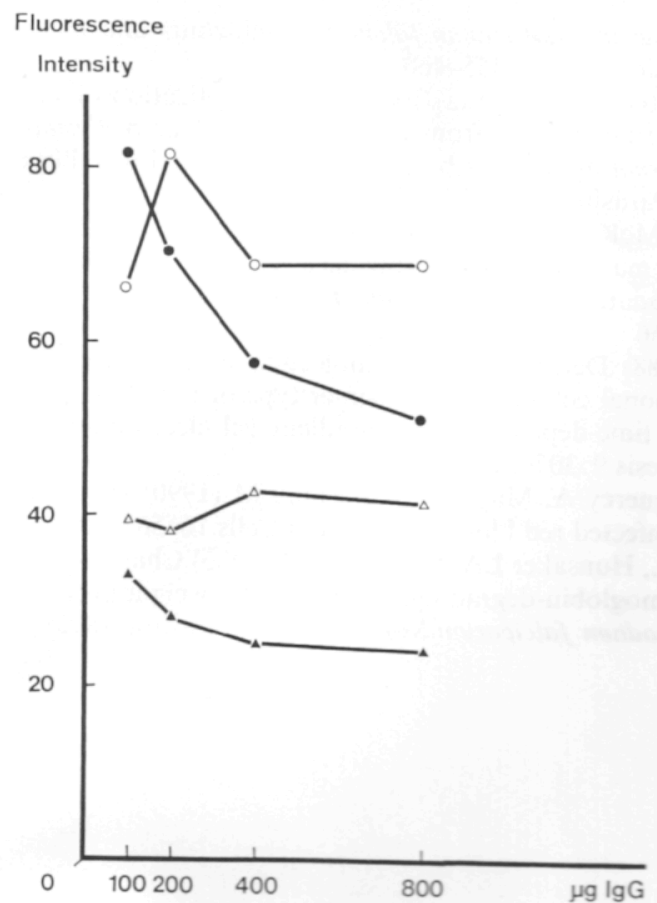

Fig. 1. Inhibition of the Pf105 proteinase activity by anti-Pf105. Freshly prepared detergent extracts from trophozoites/schizonts (protein content, $0.5 \mathrm{mg} \mathrm{ml}^{-1}$; upper two curves) and merozoites (protein content, $2 \mathrm{mg} \mathrm{ml}^{-1}$; lower two curves) were incubated for $2 \mathrm{~h}$ at $4^{\circ} \mathrm{C}$ with increasing amounts of purified IgGs from preimmune $(O, \Delta)$ and anti-Pf105 antiserum $(\bullet, \mathbf{\Delta})$ and then incubated with the synthetic peptide substrate GlcA-Val-Leu-GlyLys - AEC for $30 \mathrm{~min}$ at $37^{\circ} \mathrm{C}$ as described by Grellier et al. (1989)

described except PMSF (data not shown). The formation of the 38-kDa product (Fig. 2, lane f) was promoted in media with an acidic $\mathrm{pH}$, as was the formation of the $68-\mathrm{kDa}$ product, and could be prevented by all of the protease blockers used.

The reproducibility of the processing suggests that the protein is cleaved by specific, parasite-derived enzyme(s). However, the involvement of an autocatalytic mechanism cannot be ruled out, since the protease inhibitors that prevented processing from 105 to $97 \mathrm{kDa}$ also inhibited the Pf105 activity against the peptidic substrate. As described, processing appeared to take place in two steps (from 105 to $97 \mathrm{kDa}$ and from 97 to 68 $38 \mathrm{kDa}$ ) under different conditions, suggesting that two (or more) enzymatic systems may be involved. These enzyme(s) are as yet unknown.

The first processing step, i.e. from 105 to $97 \mathrm{kDa}$, was clearly seen in extracts from trophozoites and schizonts and could also be observed in extracts from merozoites, from which erythrocytic enzymes were excluded. It was blocked by most of the proteinase inhibitors used but not by pepstatin, PMSF or EDTA. In contrast, the second step (to 68/38) was blocked by all of the inhibitors used except PMSF. This latter processing to the smaller products was seen mainly in trophozoite/schizont extracts. The enzyme(s) responsible for the second processing step is (are) likely to be active at an acidic $\mathrm{pH}$. Malarial acid proteinases such as the food-vacuole $28-\mathrm{kDa}$ cysteine proteinase (Rosenthal et al. 1988) or

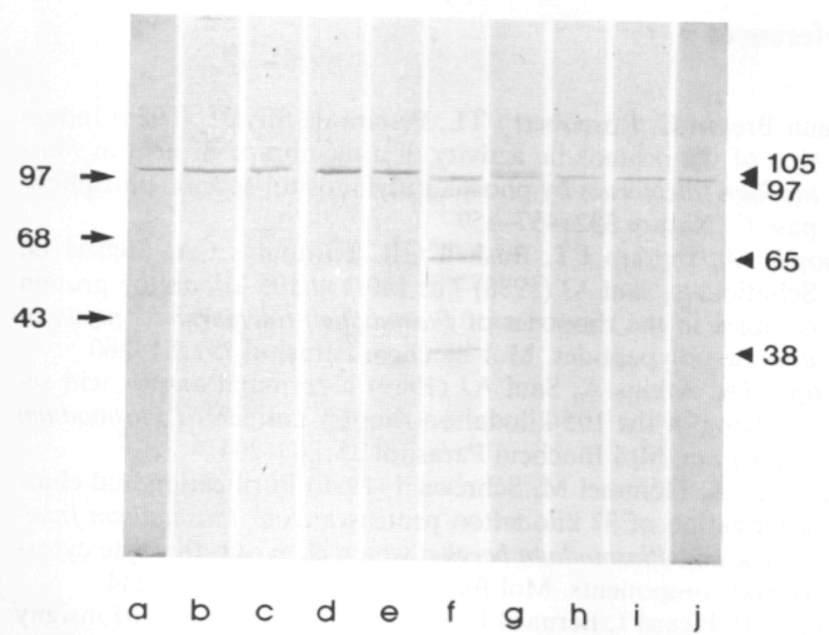

Fig. 2. Inhibition of processing of Pf105, and processing of Pf105 to the low-molecular-weight products of 97,68 and $38 \mathrm{kDa}$. The blots were made from water extracts. Lanes $a-e$, Inhibition of processing in the presence of protease blockers. Lane 1,1 mm antipain; lane $b, 3 \mathrm{~mm}$ iodoacetamide; lane $c, 0.1 \mathrm{~mm}$ leupeptin; lane $d, 1 \mathrm{~mm}$ TLCK; lane e, $1 \mathrm{~mm} \mathrm{ZnCl}_{2}$. Lanes $f, g$, Processing in the absence of proteinase inhibitors. Lane $f$, Trophozoite/schizont extract processed for $6 \mathrm{~h}$ at $4^{\circ} \mathrm{C}$, frozen and thawed; lane $g$, original merozoite extract without inhibitors, after about 2 h. Lanes $h-j$, Processing in the presence of inactive proteinase inhibitors. Lane $h, 1 \mathrm{~mm}$ EDTA; lane i, 1 mм pepstatin; lane j, 2 mм PMSF

protease S (Vander Jagt et al. 1986), both of which are responsible for hemoglobin degradation, or more recently described enzymes (Pf37, Duguercy et al. 1990; p76, Braun-Breton et al. 1988) might participate in this second step after being released during in vitro lysis of trophozoites and schizonts in aqueous acidic extracts. The enzymatic activity of the mixture of the processed products against the substrate GlcA-Val-Leu-GlyLys-AEC was rather stable at $4^{\circ} \mathrm{C}$ (over at least $24 \mathrm{~h}$ ), indicating that the processing does not affect the catalytic site of the enzyme.

The question arises as to whether or not the neutral proteinase Pf105 described herein is identical with the $105-k D a$ rhoptry antigen described by Cooper et al. (1988). These authors have not assigned an enzymatic activity to the latter protein. Both proteins, however, undergo processing that results in products of 97 and $38 \mathrm{kDa}$ (Cooper et al. 1989). Neither cryo-immuno-electron microscopy (data not shown) nor immunofluorescence showed any clear compartmentation of the Pf105 enzyme in parasite organelles such as rhoptries, suggesting that our Pf105 is not identical to the $105-\mathrm{kDa}$ rhoptry protein. Preliminary N-terminal sequence analysis of Pf105 has supported this finding (data not shown).

Acknowledgements. We thank Prof. M. Monsigny and Dr. R. Mayer (CNRS, Orléans, France) for donating the fluorogenic probes and Ms. A. Baskaya and R. Verheyen for their excellent technical assistance. This work was supported by a grant from the Max-Planck-Gesellschaft (MPG)/Centre National de la Recherche Scientifique (CNRS), by the UNDP/World Bank/WHO Special Programme for Research and Training in Tropical Diseases (TDR), the Commission of the European Communities (TSD123F), by the PROCOPE Programme and by the Fondation pour la Recherche Medicale. 


\section{References}

Braun-Breton C, Rosenberry TL, Pereira da Silva L (1988) Induction of the proteolytic activity of a membrane protein in Plasmodium falciparum by phosphatidyl inositol-specific phospholipase C. Nature 332:457-459

Cooper JA, Ingram LT, Bushell GR, Fardoulys CA, Stenzel D, Schofield L, Saul AJ (1988) The 140/130/105-kilodalton protein complex in the rhoptries of Plasmodium falciparum consists of discrete polypeptides. Mol Biochem Parasitol 29:251-260

Cooper JA, Atkins A, Saul AJ (1989) N-terminal amino acid sequencing of the 105-kilodalton rhoptry antigen of Plasmodium falciparum. Mol Biochem Parasitol 33:203-204

Deguercy A, Hommel M, Schrével J (1990) Purification and characterization of 37 kilodalton proteases from Plasmodium falciparum and Plasmodium berghei which cleave erythrocyte cytoskeletal components. Mol Biochem Parasitol 38:233-244

Grellier P, Picard I, Bernard F, Mayer R, Heidrich HG, Monsigny M, Schrével J (1989) Purification and identification of a neutral endopeptidase in Plasmodium falciparum schizonts and merozoites. Parasitol Res 75:455-460

Heidrich HG, Strych W, Mrema JEK (1983) Identification of surface and internal antigens from spontaneously released Plasmodium falciparum merozoites by radio-iodination and metabolic labeling. Z Parasitenkd 69:715-725

Rosenthal PJ, McKerrow JM, Aikawa M, Nagasawa H, Leech JH (1988) A malarial cysteine proteinase is necessary for hemoglobin degradation by Plasmodium falciparum. J Clin Invest $82: 1560-1566$

Rothe GM (1988) Determination of molecular masses, Stockes's radius, frictional coefficient and isomer type of non-denatured proteins by time-dependent pore gradient gel electrophoresis. Electrophoresis 9:307-316

Schrével J, Deguercy A, Mayer R, Monsigny M (1990) Proteases in malaria-infected red blood cells. Blood Cells 16:563-584

Vander Jagt DL, Hunsaker LA, Campos NM (1986) Characterization of a hemoglobin-degrading, low molecular weight protease from Plasmodium falciparum. Mol Biochem Parasitol 18:389400 